\title{
LOWER-FREE TROPOSPHERIC OZONE DIAL MEASUREMENTS OVER ATHENS, GREECE
}

\author{
Michail Mytilinaios ${ }^{1}$, Alexandros Papayannis ${ }^{1 *}$, and Georgios Tsaknakis ${ }^{1}$ \\ ${ }^{1}$ National Technical University of Athens, Laser Remote Sensing Unit, Phys. Dept., Zografou, Greece, \\ *apdlidar@central.ntua.gr
}

\begin{abstract}
A compact ozone differential absorption lidar (DIAL) was implemented at the Laboratory of Laser Remote Sensing of the National Technical University of Athens (NTUA), in Athens, Greece. The DIAL system is based on a Nd:YAG laser emitting at 266 $\mathrm{nm}$. A high-pressure Raman cell, filled with $\mathrm{D}_{2}$, was used to generate the $\lambda_{O N}$ and $\lambda_{\mathrm{OFF}}$ laser wavelength pairs (i.e., 266-289 $\mathrm{nm}$ and 289-316 nm, respectively) based on the Stimulated Raman Scattering (SRS) effect. The system was run during daytime and nighttime conditions to obtain the vertical profile of tropospheric ozone in the Planetary Boundary Layer (PBL) and the adjacent free troposphere.
\end{abstract}

\section{INTRODUCTION-TROPOSPHERIC OZONE}

Ozone plays a significant role in the tropospheric chemistry as the major precursor of the hydroxyl radicals $(\mathrm{OH})$, which in turn is the primary removal agent for most of the atmospheric pollutants [1]. In addition, ozone as a greenhouse gas influences the radiative balance of the troposphere and consequently the climate change [2].

Moreover, high ozone levels over urban areas contribute to the formation of photochemical smog while can cause health problems to humans and plants [3].

The ozone budget in the troposphere and its concentration changes are controlled by both chemical and dynamical processes: photochemical production in the Planetary Boundary Layer (PBL), downward transport from the stratosphere and horizontal transport from a source region [4].

Ozone is produced by photochemical reactions involving primary pollutants such as carbon monoxide (CO), nitrogen oxides $\left(\mathrm{NO}_{\mathrm{X}}\right)$ and hydrocarbons (HC), which accelerate the process $[1,3]$. The transport of ozone from the stratosphere occurs during stratospheric-tropospheric exchanges, which in the extratropics are associated mainly with tropopause folds and cutoff lows events [5-11].

Furthermore, ozone in the free troposphere can be easily transported from a source region to another, due to its relatively longer lifetime and the higher wind velocities, as detected over the Eastern Mediterranean [8-10].

\section{METHODOLOGY-EXPERIMENTAL SETUP}

\subsection{Methodology}

By applying the well-known lidar equation [12] at the two wavelengths ( $\lambda_{\mathrm{ON}}$ and $\left.\lambda_{\mathrm{OFF}}\right)$, we get the ozone concentration $\mathrm{n}_{\mathrm{O} 3}[4]$ :

$$
n_{O_{3}}(z)=\frac{1}{2 \Delta \sigma_{i}}\left[\frac{d}{d z} \ln \frac{P\left(\lambda_{\mathrm{OFF}}, z\right)}{P\left(\lambda_{O N}, z\right)}\right]
$$

where, $P_{i}=$ number of photons received at channel $i$ ( $i=O N$ or $O F F$ wavelength), $\Delta \sigma_{i}=\sigma\left(\lambda_{O N}\right)-\sigma\left(\lambda_{O F F}\right)$ for $\mathrm{O}_{3}$ and $\sigma(\lambda)=$ absorption cross section of ozone $\left(\mathrm{cm}^{2}\right)$ at wavelength $\lambda$.

The corresponding statistical error $\left(\varepsilon_{1}\right)$ if given by the following equation [4]:

$$
\varepsilon_{1}(z)=\frac{1}{2 n_{O_{3}}(z) \Delta \sigma_{i} \Delta z[N(z)]^{1 / 2}} \sqrt{\frac{2}{S N R(z)_{1}^{2}}+\frac{2}{S N R(z)_{2}^{2}}}
$$

where, $\operatorname{SNR}(z)_{i}=\frac{P_{i}(z)}{\left(P(z)_{i}+P_{b i}(z)\right)^{1 / 2}}$

and $\mathrm{P}_{b i}(\mathrm{z})$ is the atmospheric and electronic background noise at channel $i, \Delta \mathrm{z}$ is the range resolution of the measurement, and $\mathrm{N}(\mathrm{z})$ is the number of laser shots (related to the integration time).

The corresponding systematic error $\left(\varepsilon_{2}\right)$, if we omit the laser beam absorption by other gases, is given by the following equation [4]:

$\varepsilon_{2}(z)=\frac{1}{n_{O_{3}}(z) \Delta \sigma_{i}}\left[\frac{1}{2} \cdot \frac{d}{d r} \ln \frac{\beta\left(\lambda_{O N}, z\right)}{\beta\left(\lambda_{O F F}, z\right)}-\Delta \alpha_{R A Y}(\lambda, z)-\Delta \alpha_{a e r}(z, \lambda)\right]$

where, $\beta\left(\lambda_{\mathrm{i}}, \mathrm{z}\right)$ is the atmospheric backscatter coefficient at wavelength $\lambda_{\mathrm{i}}(i=O N$ or $O F F)$ at range $\mathrm{z}, \quad \Delta \alpha_{R A Y}(\lambda, \mathrm{z})=\quad \alpha_{R A Y}\left(\lambda_{\mathrm{ON}}, \mathrm{z}\right)-\alpha_{R A Y}\left(\lambda_{\mathrm{OFF}}, \mathrm{z}\right) \quad$ and $\Delta \alpha_{\text {aer }}(\lambda, \mathrm{z})=\alpha_{\text {aer }}\left(\lambda_{\mathrm{ON}}, \mathrm{z}\right)-\alpha_{\text {aer }}\left(\lambda_{\mathrm{OFF}}, \mathrm{z}\right)$, where $\alpha_{R A Y}\left(\lambda_{\mathrm{i}}, \mathrm{z}\right)$ and $\alpha_{a e r}\left(\lambda_{\mathrm{i}}, \mathrm{z}\right)$ are the extinction coefficients of 
atmospheric molecules and particles, respectively, at wavelength $\lambda_{\mathrm{i}}(i=O N$ or $O F F)$ at range $\mathrm{z}$.

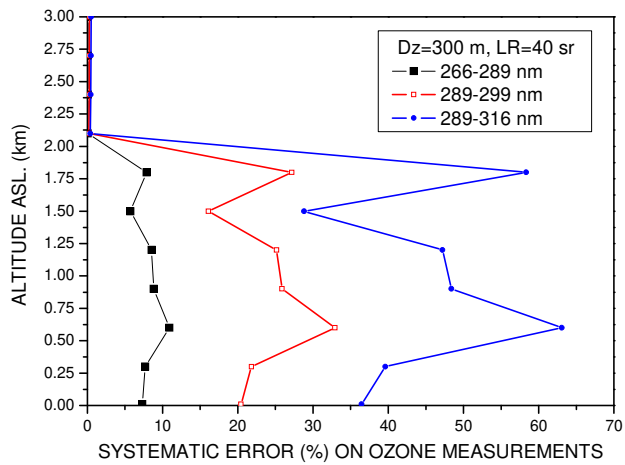

Figure 1. Systematic error $\left(\varepsilon_{2}\right)$ in \% for three different wavelength pairs: $266-289 \mathrm{~nm}, 289-299 \mathrm{~nm}$ and 289$316 \mathrm{~nm}$.

In Fig. 1 we present simulations of the systematic error $\varepsilon_{2}$, in a polluted urban atmosphere (with an intense presence of aerosols), for three wavelength pairs $(266-289 \mathrm{~nm}, 289-299 \mathrm{~nm}, 289-316 \mathrm{~nm})$, a range resolution of $300 \mathrm{~m}$ and a typical lidar ratio (LR), $\operatorname{LR}(\lambda, z)=\alpha_{\text {aer }}(\lambda, z) / \beta_{\text {aer }}(\lambda, z)$, of 40 sr. From this figure we see that we can derive the ozone profiles within the first $2 \mathrm{~km}$ (typically within the Planetary Boundary Layer) with a systematic error $\varepsilon_{2}<10 \%$, if we use the 266-289 $\mathrm{nm}$ wavelength pair.

\subsection{Experimental setup}

To produce the ON and OFF wavelength we use the Stimulated Raman Scattering (SRS) effect by optically pumping, with the $4^{\text {th }}$ harmonic of a Nd:YAG laser $(17-20 \mathrm{~mJ} /$ pulse at $266 \mathrm{~nm})$, a $1-\mathrm{m}$ long high-pressure Raman cell filled with a Raman active gas ( $\mathrm{D}_{2}$ at $\left.14 \mathrm{~atm}\right)$.

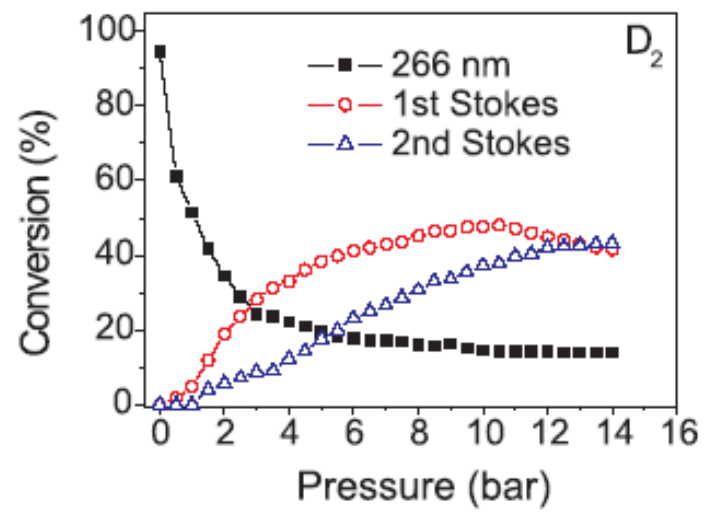

Figure 2. Conversion efficiency (\%) at the exit of a 1-m long Raman cell, at both the $1^{\text {st }}$ and $2^{\text {nd }}$ Stokes wavelengths (289 and $316 \mathrm{~nm}$, respectively) and $266 \mathrm{~nm}$ [13].
Previous experiments [13] have shown that at a pressure of 14 bar $\left(D_{2}\right)$ we can achieve an energy conversion efficiency at the exit of the Raman cell of the order of $40 \%$ at both the $1^{\text {st }}$ and $2^{\text {nd }}$ Stokes wavelength (289 and $316 \mathrm{~nm}$, respectively), and of $\sim 18 \%$ at the fundamental wavelength $266 \mathrm{~nm}$ (Fig. 2). By adding $\mathrm{H}_{2}$ in the Raman cell, the wavelength of $299 \mathrm{~nm}$, can also be generated [13].

The Differential Absorption Lidar (DIAL) system for ozone profiling in the lower troposphere of the Laser Remote Sensing Unit (LRSU) of NTUA (EOLE and DIAL lidar systems) is based in Athens $\left(37.96^{\circ} \mathrm{N}\right.$, $23.78^{\circ} \mathrm{E}, 220 \mathrm{~m}$ a.s.l.). The system is based on the $4^{\text {th }}$ harmonic of a pulsed Nd:YAG laser, emitting 17-20 $\mathrm{mJ} /$ pulse at $266 \mathrm{~nm}(10 \mathrm{~Hz}$ repetition rate). It is used to optically pump a $1-\mathrm{m}$ long stainless steel Raman cell filled with $\mathrm{D}_{2}(14 \mathrm{~atm})$, through the SRS effect. The laser pulses produced at $266 \mathrm{~nm}, 289 \mathrm{~nm}$ and $316 \mathrm{~nm}$, have energies of the order of $3 \mathrm{~mJ}(266 \mathrm{~nm})$, and $6 \mathrm{~mJ}$ (both at 289 and $316 \mathrm{~nm}$ ).

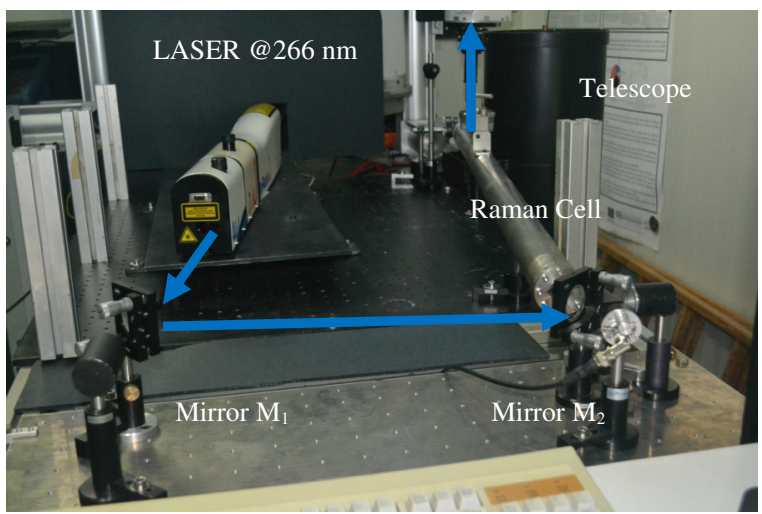

Figure 3. The experimental setup of the LRSU ozone DIAL system (emitting and receiving units). The ON and OFF DIAL wavelength are produced from a highpressure Raman call filled with $\mathrm{D}_{2}(14 \mathrm{~atm})$.

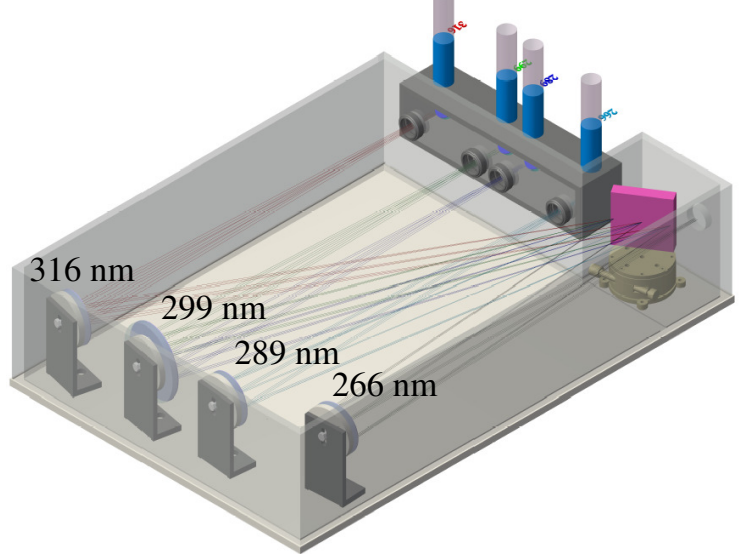

Figure 4. The multi-wavelength ozone spectrometer (auto CAD simulations) for the spectral separation of the $O N$ and OFF lidar signals. 
A receiving Newtonian telescope of $250 \mathrm{~mm}$ diameter and $1125 \mathrm{~m}$ focal length ( $\mathrm{f} / 4.5)$ is used to collect the backscatter laser beams at 266, 289 and $316 \mathrm{~nm}$ (Fig. 3). This telescope is optically coupled to a discriminating spectrometer through a pure $\mathrm{SiO}_{2}$ optical fiber [14]. The backscattered lidar signals between $266-316 \mathrm{~nm}$ are spectrally separated by a Czerny-Turner grating spectrometer (4960 lines $/ \mathrm{mm}$ ) with a spectral resolution better than $0.5 \mathrm{~nm}$ (Fig. 4). Four concave mirrors are used to focus the lidar signals at the photocathode of compact photomultiplier tubes (PMTs) at four respective wavelengths: 266, 289, 299 and $316 \mathrm{~nm}$. High performance transient recorders (Licel $\mathrm{GmbH}$ ) are used to digitize the received lidar signals (12 bits - 40 $\mathrm{MHz}-8192$ signal bins) at 266, 289 and $316 \mathrm{~nm}$. The typical number of averaged lidar signals is 4000 , corresponding to 6 min time resolution.

\section{EXPERIMENTAL RESULTS}

In Fig. 5, we present the vertical profile of the ozone number density $\left(\mathrm{moles} / \mathrm{cm}^{3}\right)$ obtained during daytime (10:15-14:21 UTC) over Athens, on 02 December 2016, based on a combination of two-wavelength pairs: 266-289 $\mathrm{nm}$ (inside the PBL, from ground up to $2 \mathrm{~km}$ height) and $289-316 \mathrm{~nm}$ (in the free troposphere). This profile has been corrected for the atmospheric backscatter and for the molecular and particulate differential extinction (cf. equation 4). The latter one has been based on aerosol measurements obtained by our DIAL system at $316 \mathrm{~nm}$ and at 355 $\mathrm{nm}$ by the collocated multi-wavelength Raman lidar of NTUA (EOLE system).

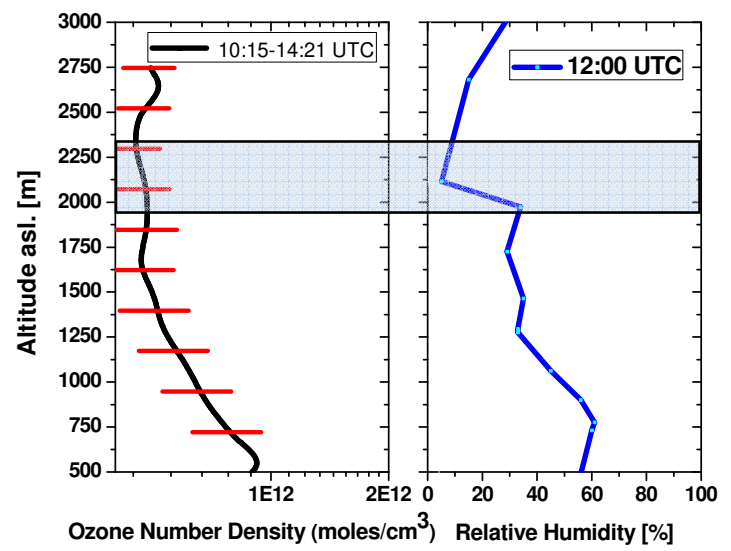

Figure 5. left: Vertical profile of the ozone number density (moles $\left./ \mathrm{cm}^{3}\right)$ and right: relative humidity, obtained over Athens during daytime by the NTUA DIAL system (wavelength pairs 266-289 $\mathrm{nm}$ and 289$316 \mathrm{~nm}$ ) and a radiosonde, respectively.
The corresponding vertical profile of the relative humidity (RH) obtained by radiosonde (cf. Fig. 5right) launched by the Hellenic National Meteorological Service (HNMS), shows a very low value of $\mathrm{RH}(6 \%)$ observed around $2.1 \mathrm{~km}$ height. This very low value of RH may be related to a recent stratospheric-tropospheric transport (STT) event, occurred over Athens. This can be corroborated by three factors:

a) High values of absolute vorticity and winds field over Athens (observed a few hours before) at 500 hPa surface (cf. Fig. 6),

b) Total ozone data showing a cut-off low (denoted by a brown circle) event [5-7, 9-10] with high ozone values over Greece (cf. Fig. 7).

c) Strong downward winds around $2 \mathrm{~km}$ height (skew-T diagram not shown).

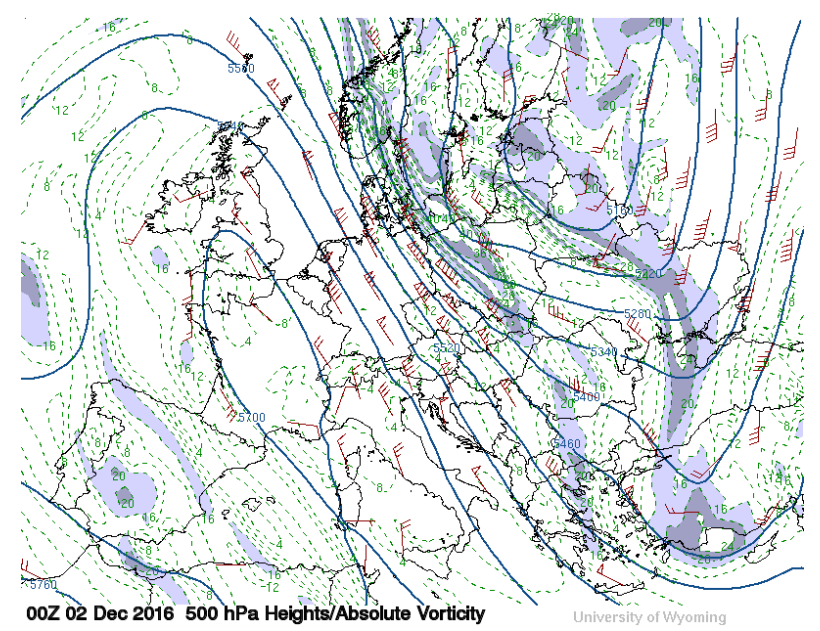

Figure 6. Absolute vorticity map and winds field at 500 hPa surface, on 02 December 2016 (00:00 UTC) [image credit: University of Wyoming, USA].

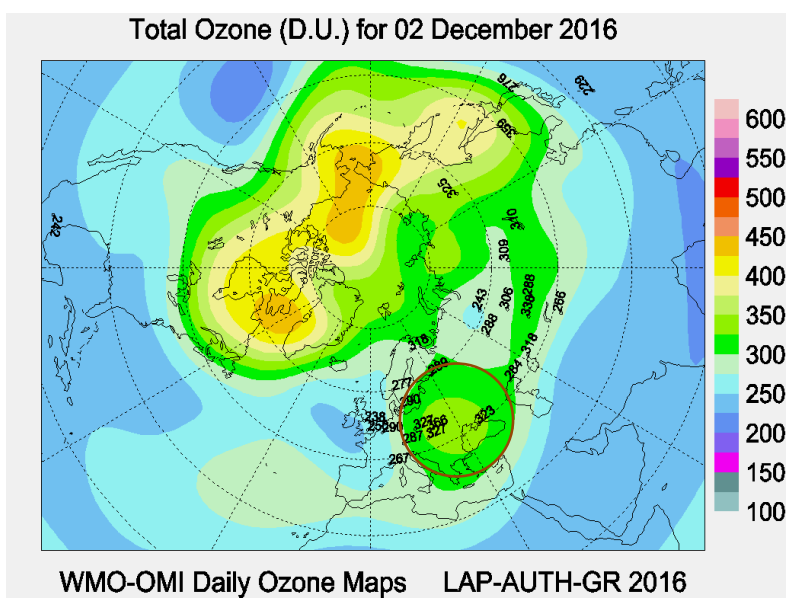

Figure 7. Total ozone map obtained by OMI-Aura satellite on 02 December 2016. 


\section{CONCLUSIONS}

In this paper we presented a typical vertical profile of the ozone number density obtained over Athens, using a two-wavelength pair DIAL system (266-289 $\mathrm{nm}$ and 289-316 nm), which coincided with a deep STT event [9-11], observed down to $2.1 \mathrm{~km}$ height.

Systematic ozone measurements are to be performed over Athens, starting on February 2017, during daytime and nighttime.

\section{ACKNOWLEDGMENTS}

The AutoCAD simulation of Figure 4 has been kindly provided by Dr. Jacques Porteneuve (IPSL, CNRS, France). Total ozone map has been provided by the WMO Ozone mapping center (LAP-AUTH, Greece). Radiosonde data has been obtained by the Hellenic National Meteorological Service. Absolute vorticity map and winds field, at $500 \mathrm{hPa}$ surface, have been provided by the University of Wyoming (USA).

\section{References}

[1] Brasseur G., Orlando J. and Tyndall J., (Eds.), Atmospheric Chemistry and Global Change, Oxford University Press, pp. 654, 1999.

[2] Stevenson, D. S., et al., 2013: Tropospheric ozone changes, radiative forcing and attribution to emissions in the Atmospheric Chemistry and Climate Model Intercomparison Project (ACCMIP), Atmos. Chem. Phys., 13, 3063-3085.

[3] Finlayson-Pitts, B. J., and Pitts, J. N., Jr., 1999: Chemistry of the Upper and Lower Atmosphere, Academic Press, USA, pp. 969.

[4] Papayannis, A., Ancellet, G., Pelon, J., and Mégie, G., 1990: Multiwavelength lidar for ozone measurements in the troposphere and the lower stratosphere, Appl. Opt., 29, 467-476.

[5] Ancellet, G., Beekmann, M., Papayannis, A., 1994: Impact of a cut-off low development on downward transport of ozone in the troposphere, $J$. Geophys. Res., 99(D2), 3451-3468.

[6] Galani, E., Balis, D., Zanis, P., Zerefos, C., Papayannis, A., Wernli, H., and Gerasopoulos, E., 2003: Observations of stratosphere-totroposphere transport events over the eastern Mediterranean using a ground-based lidar system, J. Geophys. Res., 108(D12), 8527, doi:10.1029/2002JD002596.

[7] Stohl, A., et al., 2003: Stratospheric-tropospheric exchange. A review and what we have learned from
STACCATO, J. Geophys. Res., 108(D12), 8516, doi:10.1029/2002JD002490.

[8] Kourtidis, K., et al., 2002: Regional levels of ozone in the troposphere over the eastern Mediterranean, J. Geophys. Res., 107(D18), 8140, doi:10.1029/ 2000JD000140, 2002.

[9] Papayannis, A., Balis D., Zanis P., Galani E., Wernli H., Zerefos C., Stohl A., Eckhardt S., Amiridis V., 2005: Sampling of an STT event over the Eastern Mediterranean region by lidar and electrochemical sonde. Ann. Geophys., 23, 20392050.

[10] Akritidis, D., Pozzer1, A., Zanis, P., Tyrlis, E., Škerlak, B., Sprenger, M., and Lelieveld, J., 2016: On the role of tropopause folds in summertime tropospheric ozone over the eastern Mediterranean and the Middle East, Atmos. Chem. Phys., 16, 1402514039 .

[11] Trickl, T., et al., 2016: How deep are stratospheric intrusions LUAMI 2008, Atmos. Chem. Phys., 16, 8791-8815.

[12] Measures. R., 1992: Laser Remote Sensing. Fundamentals and Applications, Krieger Publ., pp. 510.

[13] Tzortzakis, S., Tsaknakis G, Papayannis A, Serafetinides A. A., 2004: Investigation of the spatial profile of stimulated Raman scattering beams in $\mathrm{D}_{2}$ and $\mathrm{H}_{2}$ gases using a pulsed Nd:YAG laser at 266 nm, Appl. Phys., B79, 71-75.

[14] Kalabokas, P., Papayannis, A., Tsaknakis, G. and Ziomas, I., 2012: A study on the atmospheric concentrations of primary and secondary air pollutants in the Athens basin performed by DOAS and DIAL measuring techniques, Science Total Environ., 414, 556-563. 